\title{
STRATEGI SOSIALISASI IZIN MENDIRIKAN BANGUNAN DI DESA BILA KECAMATAN DUA PITUE KABUPATEN SIDENRENG RAPPANG
}

\author{
${ }^{1)}$ Syafaruddin, ${ }^{2)}$ Mirnawati, ${ }^{3)}$ Sapri, ${ }^{4}$ Muhammad Arisal Asad \\ Fakultas IImu Sosial dan IImu Politik Universitas Muhammadiyah Sidenreng Rappang \\ syafarta@umsrappang.ac.id \\ mirnawati43162031b@gmail.com \\ sapritajuddin272@yahoo.co.id \\ arisalasad@yahoo.co.id
}

\begin{abstract}
Abstrak
strategi sosialisasi izin mendirikan bangunan (IMB) di Desa Bila Kecamatan Dua Pitue Kabupaten Sidenreng Rappang. Penelitian ini bertujuan untuk mengetahui strategi iziin mendirikan bangunan di Desa Bila Kecamatan Dua Pitue Kabupaten Siidenreng Rappang dan untuk mengetahui faktorfaktor yang memengaruhi strategi sosialisasi izin mendirikan bangunan di Desa Bila Kecamatan Dua Pitue Kabupaten Sidenreng Rappang. Populasi dari penelitian ini adalah masyarakat Desa Bila sebanyak 3.028 orang dengan mengambil sampel 97 oramg yang ditarik dengan menggunakan rumus slovin. Teknik penarikan sampel yang diigunakan adalah Purpossive Sampling. Tipe penelitan inii adalah deskriptif kuantitatif. Tehnik pengumpulan data yang digunakan adalah observasi, wawancara, kuesioner dan studi pustaka.Tehnik analisis data yang digunakan adalah statistic deskriptif dan dengan bantuan aplikasi SPSS versi 16. Hasil penelitian menunjukkan bahwa Strategi Sosialisasi Izin Mendirikan Bangunan di Desa Bila dipandang dari tiga indikator proses sosialisasi : persiapan, siap bertindak dan peneriman norma kolektif memperoleh hasil $58 \%$ dari hasil yamg diharapkan $100 \%$. Inii menujukkan bahwa strategi sosialisasi izin mendirikan bangunan di Desa Bila berada pada kategori kurang baik dan masih perlu ditinjau kembali. Faktor-faktor yang memengaruhi strategi sosialisasi izin mendirikan bangunan dii Desa Bila dipandang dari faktor eksternal : pendidikan, lingkungan, pekerjaan dan faktor internal : motivasi, minat, kemampuan memperoleh hasil $57 \%$ dari hasil yang diharapkan $100 \%$. Inu menunjukkan bahwa faktor-faktor yang memengaruhi strategi sosialisasi iziin mendirkan bangunan berada pada kategori kurang baik.
\end{abstract}

Kata Kunci : Strategi dan Sosialisasi

\begin{abstract}
strategy of socializing the establishment of buldings in the Bila village, Dua Pitue district of sidenreng rappang regency. This study aims to determine the strategy of socializing building permits that from building in the Bila village, Dua Pitue district of Sidenreng Rappang regency and to find out the factors that influence the socialization strategy to build a building license iin the Bila village Dua Ptitue district of Sidenreng Rappang Regency. The population of this study was the village community if as many as 3.028 people by taking a sample of 97 people withdrawal technique used is purpossive sampling. This typpe of rescearch is descriptive quantitative. The data collcection technique used is observation, interview, questionnaire and literature study. Thee technique of the data abalysis used is descriptive statistics and with the help of the SPSS version 16 application. The result showed that the socialization strategy for establishing building licenses in Bila village viewed from three indicators of the socialization process : preparation, ready to act and the acceptance of collective norms obtained a result of $58 \%$ of the expected result of $100 \%$. This shows that the socialization strategy of establishing building permits in the Bila village in the category is not good and still needs to be reviewed. Factors that influence the socialization strategy of establishing building permits in Bila village viewed from external factors : education, environment, employment adn internal factors : motivation, interest, aability to get $57 \%$ of the expected result $100 \%$. This shows that the factors that affect the socialization strategy of establishing building permits are in the poor category.
\end{abstract}

Keywords : Strategy and Socialization

Volume 8 | Nomor 3 | Edisi Desember 2020 | JIA 


\section{A. PENDAHULUAN}

Indonesia merupakan negara yang sedang berkembang merupakan salah satu negara yang memiliki luas wilayah yang sangat luas dan terdiri dari beberapa kepulauan yang terdapat dari Sabang sampai Merauke, dari zaman orde baru sampai reformasi Negara Indonesia terlalu terfokus melakukan pembangunan di daerah ibukota atau dearah sekitaran pulau Jawa, daerahdaerah yang jauh dari ibukota belum sepenuhnya mendapatkan pembangunan yang merata. Harapan masyarakat kepada pemerintah yaitu melakukan kewajiban dalam menjalankan pemerintahan yang baik (good governance) didefenisikan di dalam bidang ekonomi, sosial, politik di Negara Indonesia.

Undang-Undang Nomor 28 Tahun 2002 Tentang Bangunan Gedung Pasal 1 ayat (1) disebutkan Bangunan gedung adalah wujud fisik hasil pekerjaan konstruksi yang menyatu dengan tempat kedudukannya, sebagian atau seluruhnya berada di atas atau di dalam tanah dan air, yang berfungsi sebagai tempat manusia melakukan kegiatannya, baik untuk tempat tinggal, kegiatan keagamaan, kegiatan usaha, kegiatan sosial dan budaya. Lebih lanjut dikatakan dalam ayat (9) bahwa Pemilik bangunan gedung adalah orang, badan hukum, kelompok orang, atau perkumpulan, yang menurut hukum yang sah sebagai pemilik gedung.

Berdasarkan Peraturan Daerah Pemerintah Kabupaten Sidenreng Rappang bahwa dlaam rangka tertib administrasi dan kelancaran proses pemungutan Retribusi Izin Mendirikan Bangunan sesuai dengan ketentuan dalam Peraturan Daerah Kabupaten Sidenreng Rappang Nomor 2 Tahun 2011 tentang Retribusi Izin Mendirikan Bangunan, maka masyarakat Kabupaten Sidenreng Rappang diharuskan memiliki izin mendirikan bangunan sebagai syarat untuk mendirikan bangunan di atas tanah. Dengan ditetapkan Peraturan Daerah ini, diharapkan akan memberikan landasan hukum, sekaligus meningkatkan pelayanan kepada masyarakat khusunya di bidang perizinan bangunan, pengawasan dan ketertiban terhadap bangunan yang berada dii Wilayah Kabupaten Sidenreng Rappang.

Sosialisasi adalah proses belajar yang dilakukan oleh setiap orang untuk berbuat atau bertingkah laku sesuai dengan norma-norma yng berlaku di masyarakat.
Hasil pengamatan awal pada bulan februari 2020 yang dlakukan dan beberapa infomasi yang diperoleh oleh peneliti, ditemukan fakta bahwa masih banyaknya bangunan hunian (rumah) yang tidak memiliki izin mendirikan bangunan daripada bangunan hunian (rumah) yang memiiliki izin mendirikan bangunan. Di Desa Bila terdapat beberapa masyarakat yang memiliiki izin mendirikan bangunan yang berada di jalan poros sedangkan di bagian lorong-lorong desa sebagian besar masyarakat tidak memiliki izin mendirikan bangunan tersebut bahkan masyarakat tidak mengetahui tentang adanya aturan izin mendirikan bangunan. Menanggapi soal ketidaktahuan masyarakat tentang izin mendirikan bangunan tersebut, Sanriadi, S.A.P selaku Sekertaris Desa Bila mengatakan bahwa Pihak Pusat Pelayanan Terpadu Satu Pintu Kabupaten Sidenreng Rappang pernah melakukan sosialisasi di Kecamatan Pitu Riawa pada tahun 2019 dengan mengundang masing-masing perangkat desa dan perangkat kecamatan dari Pitu Riawa, Dua Pitue dan Pitu Riase untuk mengikuti sosialisasi yang membahas tentang persyaratan untuk mengajukan izin mendirikan bangunan dan sanksi bagi masyarakat yang tidak memiliki izin mendirikan bangunan. Untuk selanjutnya sosialisasi tersebut diharapkan akan sampai kepada masyarakat melalui perangkat desa dan kecamatan yang sudah mengikuti sosialisasi tersebut sebelumnya, namun dari pihak desa sendiri belum melaksanakan sosialisasi tentang izin mendirikan bangunan tersebut. (Senin, 03 Februari 2020)

Berdasarkan fakta yang ditemukan di lapangan tentang luas wilayah, kondisi topografi dan kepadatan penduduknya yang lebih banyak dan informasi dari sekertaris Desa Bila. Maka dapat disimpulkan bahwa pelaksanaan sosialisasi izin mendirikan bangunan di Desa Bila bisa lebih dimaksimalkan. Peran sosialisasi terhadap partisipasi masyarakat pada program pemerintah masih kurang dan sering kali masyarakat tidak ikut dalam pelaksanaan program pemerintah dalam menunjang pembangunan daerah. Hal tersebut sangat disayangkan, mengingat partisipasi masyarakat sangat diperlukan dalam kelancaran pelaksanaan program pemerintah. Karena semua hasil dari 
pelaksanaan program pemerintah tersebut masyarakatlah yang akan menikmati hasilnya. Dengan demikian, peneliti tertarik untk mengetahui Strategi Sosialisasi Izin Mendirikan Bangunan di Desa Bila Kecamatan Dua Pitue Kabupaten Sidenreng Rappang dengan tujuan untuk mengetahui strategi sosialisasi izin mendirikan bangunan di Desa Bila Kecamatan Dua Pitue Kabupaten Sidenreng Rappang dan untuk mengetahui Faktor-faktor yang memengaruhi strategi sosialisasi izin mendirikan bangunan di Desa Bila Kecamatan Dua Piitue Kabupaten Siidenreng Rappang.

Menurut Juach dan Glueek (akdon, 2011) strategi adalah rencana yang disatukan, menyeluruh dan terpadu yang mengaitkan keungulan strategi organisasi dengan tantangan lingkungan dan dirancang untuk memastikan bahwa tujuan utama organisasi dapad dicapai melalui pelaksanaan yang tepat oleh organisasi.

Pada dasarnya srategi sangat penting dipahami oleh setiap orang, baik itu eksekutif, manajer, kepala atau ketua, direktur, pejabat senior dan junior, pejabat tinggi, menengah maupun rendah. Hal ini harus dipahami karena strategi dilaksanakan oleh setiap orang pada setiap tingkat. Merujuk pada pandangan Higgins (salusu, 2006) yang menjelaskan adanya empat tingkatan strategiii. Keseluruhannya disebut Master Strategy, yaitu : enterprise strategy, corporate strategy, business strategy dan functional strategy.

1. Enterprise Strategy. Strategi ini berkaitan dengan respon masyarakat. setiap organisasi mempunyai hubungan dengan masyarakat. masyarakat adalah kelompok yang berada di luar organisasi yaag tidak dapat dikontrol.

2. Corporate Strategy. Strategi ini berkaitan dengan misi organisasi, sehingga sering disebut Grand Strategy yang meliputi bidang yang digeluti oleh suatu organisasi.

3. Business Strategy. Strattegi pada tingkat ini menjabarkan bagaimana menempatkan organisasi di hati para penguasa, pengusaha, donatur dan sebagainya.

4. Functinal Strategy. Strategi ini merupakan strategi pendukung sekaligus penunjang suksesnya strategi lainnya.

Tingkat-tingkat strategi itu merupakan kesatuan yang bulat dan menjadi isyarat bagi setiap pengambil keputusan tertinggi bahwa menggelola organisasi tidak boleh dilihat darii sudut kerapian administrasi semata, tetapi juga hendaknya mempertimbangkan soal kesehatan dan ekonomi.

Menurut Charles R Wright (Setyoningtias, 2018) sosialisasi adalah proses ketika indvidu mendapatkan kebudayan kelompoknya dan menginternalisasikan sampai tingkat tertentu norma-norma sosialnya, sehingga membimbing orang tersebut untuk memperhitungkan harapan-harapan orang lain. Salah satu teori peran yang dikaitkan dengan sosialisasi ialah teori George Helbert Mead. Dalam teorinya, Mead menguraikan tahap pengembangan diri manusiia. Manusia yang baru lahir belum mempunyai diri. Dirii manusia berkembang secara bertahap melalui interaksi dengan anggota masyarakat lain. Menurut George Herbert Mead (Madya, 2018) pengembangan diri manusia berlangsung melalui tahap-tahap sebagai berikut :

1. Tahap Persiapan (Preparatory Stage). Tahap awal dalam sosiialisasi yang dilakukan manusia, dimulai sejak lahir ke dunia. Pada tahap inilah seseorang sudah memiiliki persiapan untuk melakukan tindakan sesuai dengan lingkungan. Martin Susilo (Shobah. N, 2015) mengatakan bahwa kesiapan merupakan kombinasi dari kemampuan dan keimginan yang berbeda yang ditunjukkan seseorang psda tiap-tiap tugas yang diberikan.

2. Tahap Siap Bertindak (Game Stage). Tahap siap bertindak, peniruan yang dilakukan sudah mulaii berkurang dan digantikan peran secara langsung dimainkan sendiri dengan penuh kesadaran. Kemampuan menenpatkan diiri pada posisi orang lain pun meningkat, sehingga memungkinkan adanya kemampuan bermain secara bersamasama. Kesadaran adanya tuntutan untuk membela keluarga dan bekerja sama dengan orang disekitarnya.

3. Tahap Penerimaan Norma Kolektif (Generalized Stage). Pada tahap ini seseorang telah dianggap dewasa, dapat menempatkan dirinya pada posisi masyarakat secara luas. Individu dapat bertenggang rasa tidak hanya dengan orang-orang yang berinteraksi dengannya tapi juga dengan masyarakat luas. Manusia dewasa menyadari pentingnya peraturan, kemampuan bekerja sama 
bahkan dengan orang lain yang tidak dikenalnya, dengan perkembangan diri pada tahap ini telah menjadikan individu sebagai warga masyarakat dalam arti sepenuhnya.

Peraturan Daerah Kabupaten Sidenreng Rappang Nomor 02 Tahun 2011 tentang Retribusi Izin Mendirikan Bangunan. Izin mendirikan bangunan yang selanjutanya disebut IMB adalah perizinan yang diberikan oleh Pemerintah Daerah kepada pemohon untuk membangun baru, rehabilitasi/renovasi, dan/atau memugar dalam rangka melestarikan bangunan sesuai dengan persyaratan administratif dan persyaratan teknis yang berlaku. Menurut Susanta (Saputra, 2017) berpendapat bahwa izin mendirikan bangunan (IMB) adalah izin yang diberikan oleh Pemerintah Daerah kepada pribadi, sekelompok orang atau badan untuk membangun dalam rangka pemanfaatan ruang sesuai dengan izin yang diberikan karena telah memenuhi ketentuan dari berbagai aspek, baik pertahanan, teknis, perencanaan serta lingkungan. Adapun tujuan izin mendirikan bangunan yaitu sebagai berikut :

1. Mewujudkan bangunan gedung yang memenuhi persyaratan administratif dan persyaratan teknis bangunan gedung sesuai dengan fungsi dan tata ruang, yang diselenggarakan secara tertib untuk menjamin keandalan teknis bangunan gedung.

2. Mewujudkan kepastian hukum dalam penyelenggaraan izin mendirikan bangunan.

Adapun Faktor yang mempengaruhi proses sosialisasi sebagai berikut:

1. Faktor Eksternal. Faktor eksternal merupakan faktor ekstrinsik yang berada di luar diri individu, bukan bagian dari tubuhnya atau psikologisnya namun sangat berpengaruh pada proses sosialisasinya. Misalkan pendidikan, lingkungan masyarakat sekitarnya dan jenis pekerjaan yang ia jalani.

2. Faktor internal. Faktor internal merupakan faktor yang ada di dalam diri seseorang.Faktor ini menyangkut motivasi, minat serta kemampuan yang dimiliki seseorang dalam rangka menyesuaikan diri dengan tata pergaulan yang ada dalam masyarakat seperti kesiapan atau kematangan pribadi seseorang, keinginan yang kuat menyangkut bakat dan minat seseorang dan kecerdasan atau IQ yang dapat memengaruhi proses sosialisasi yaitu Motivasi, Minat, dan Kemampuan

\section{B. METODE PENELITIAN}

Penelitian ini, peneliti hanya menggunakan satu variabel, yaitu strategi sosialisasi. Penelitian ini menggunakan tipe penelitian deskriptif kuantitatif, dengan metode ini diharapkan dapat memberikan gambaran secara cermat, jelas dan objektif mengenai masalah yang sedang diteliti. Populasi pada penelitian ini sebanyak 3.028 jiwa yang merupakan penduduk di Desa Bila. Jumlah sampel adalah 97 orang. Tehnik penarikan sampel yang digunakan yakni Nonprobability Sampling dalam Ahmad (2015:141) mengatakan bahwa tehnik penarikan sampel yang tidak memberi peluang atau kesempatan yang sama untuk setiap anggota populasi untuk dipilih menjadi sampel. Teknik nonprobability sampling, yang digunakan adalah Purpossive Sampling tekhnik penentuan sampel berdasarkan pertimbangan tertentu, yaitu memilih sampel atau responden dengan pertimbangan berusia 18 hingga 50 tahun yang sudah memiliki bangunan atau sedang membangun.

Tehnik Pengumpulan data yang digunakan adalah Observasi, Wawancara, Kuesioner, dan Studi Pustaka sedangkan tteknik analisis data yang digunakan adalah statistik deskriptif dan dengan bantuan SPSS versi 16. Hasil analisis berupa statistik deskriptif, uji kualitas (uji validitas validitas dan uji reliabilitas).

\section{HASIL DAN PEMBAHASAN}

1. Hasil penelitian Strategi Sosialisasi (X) a.Tahap persiapan : 1). Informasi sosialisasi izin mendirikan bangunan yang diberikan oleh pihak pelaksana (pelayanan terpadu satu pintu) sebesar $60 \%$, 2) Kemampuan pihak pelaksana (pelayanan terpadu satu pintu) menggunakan media massa untuk menginformasikan sosialisasi izin mendirikan bangunan sebesar $56 \%$, 3) Kemampuan dari pihak pelaksana (pelayanan terpadu satu pintu) mensosialisasikan (menjelaskan) tentang izin mendirikan bangunan sebesar 58\%. 4) Cara 
pihak pelaksana (pelayanan terpadu satu pintu) mendorong masyarakat mengikuti sosialisasi izin mendirikan bangunan sebesar $58 \%$. 5) Kemampuan bekerjasama dari pihak pelaksana (Pelayanan Terpadu Satu Pintu) dengan Pemerintah Desa Bila dalam melaksanakan sosialisasi izin mendirikan bangunan sebesar $58 \%$. Berdasarkan dari uraian tersebut, maka dapat disimpulkan bahwa strategi sosialisasi di Desa Bila berada pada Kategori Kurang Baik dengan Persentase 58\%.

2. Hasil penelitian faktor-faktor yang memengaruhi strategi sosialisasi izin medirikan bangunan : a. Faktor Eksternal : 1) Keadaan lingkungan desa bila sebagai tempat dilaksanakannya sosialisasi izin mendirikan bangunan sebesar $54 \%$.

2) Hasil pekerjaan pelayanan terpadu satu pintu melaksanakan sosialisasi izin mendirikan bangunan sebesar $58 \%$. b. Faktor Eksternal 1) Dorongan atau motivasi yang diberikan pemerintah desa kepada masyarakat untuk mengikuti sosialisasi izin mendirikan bangunan sebesar 59\%. 2) Tanggapan masyarakat desa bila untuk mengikuti sosialisasi izin mendirikan bangunan sebesar 56\%. 3) Kemampuan pemerintah desa menyampaikan sosialisasi izin mendirikan bangunan sebesar $60 \%$. Maka dapat disimpulkan bahwa faktor-faktor yang memengaruhi strategi sosialisasi izin mendirikan bangunan di Desa Bila berada pada akategori Kurang Baik dengan persentase $57.4 \%$

Berdasarkan output uji validitas item. Berdasarkan dari output di atas untuk menguji tingkat validitas data yakni diketahui bahwa 5 item pertanyaan dalam mengukur variabel Strategi Sosialisasi (X) dinyatakan valid dengan nilai Corrected item-total correltion lebih besar dari $>0,25,0,30$ (corrected item-total correlation $>0.25,0.30$ ), yaitu X1 : 0.297, X2:0.604, X3:0.545,
$X 4: 0.373, X 5: 522$. Berdasarkan output uji validitas item. Berdasarkan dari output di atas untuk menguji tingkat validitas data yakni diketahui bahwa 5 item pertanyaan dalam mengukur Faktor-faktor yang memengaruhi strategi sosialisasi dinyatakan valid dengan Nilai Corrected item-total correlation lebih besar dari $>0,25,0,30$ (corrected item-total correlation > 0.25, 0.30), yaitu F1:0.546, F2:0.562, F3:0.388, F4:0.673, F5:0.557. Berdasarkan tentang jumlah data yang valid untuk diproses dan data yang dikeluarkan, serta persentasenya. Diketahui bahwa data atau case yang valid jumlahnya 97 dengan persentase $100 \%$ dan tidak ada data yang dikeluarkan (exclude).

Output tersebut sdbagai hasil dari reliabilitas cronbach alpha. Berdasarkan output tabel reliability statistics di atas, kuesioner penelitian dalam mengukur varibel Strategi Sosialisasi (X) reliabel karena Cronbach Alpha yang diperoleh adalah sebesar 0.698 yang berarti lebih besar dari $0.60(0.689>0.60)$. Output tersebut sdbagai hasil dari reliabilitas cronbach alpha. Berdasarkan output tabelreliability statistics di atas, kuesioner penelitian dalam mengukur Faktor-fakor yang memengaruhi Strategi Sosialisasi reliabel karena Cronbach Alpha yang diperoleh adalah sebesar 0.772 yang berarti lebih besar dari $0.60(0.772>0.60)$.

Penerapan Peraturan Daerah Kabupaten Sidenreng Rappang No. 2 Tahun 2011 tentang izin mendirikan bangunan dikatakan baik apabila masyarakat yang memiliki bangunan maupun yang sedang membangun sudah memiliki surat izin mendirikan bangunan. Untuk itu, strategi sosialisasi yang baik akan mendukung terrealisasikannya Peraturan Daerah ini dalam penerapan izin mendirikan bangunan yang menyeluruh di masyarakat. Sosialisasi yang diberikan oleh pihak pelayanan terpadu satu pintu akan membantu masyarakat untuk memahami dengan jelas maksud dan tujuan dari peraturan daerah tersebut. Hal ini sesuai dengan yang dikemukakan oleh oleh Jauch dan Glueck (akdon, 2011) menyebutkan bahwa strategi adalah rencana yang disatukan, menyeluruh dan terpadu yang mengaitkan keunggulan strategi organisasi dengan tantangan lingkungan dan dirancang untuk memastikan bahwa tujuan utama organisasi dapat dicapai melalui pelaksanaan yang tepat oleh organisasi. 
Berdasarkan data distribusi frekuensi variabel strategi sosialisasi izin mendirikan bangunan dapat dilihat bahwa tingkat capaian responden sebesar $58 \%$. Ini memperlihatkan bahwa nilai tingkat capaian responden berada pada kategori kurang baik. Maka dari itu strategi sosialisasi izin mendirikan bangunan masih perlu ditingkatkan, lebih utamanya dapat mengoptimalkan adanya izin mendirikan bangunan bagi masyarakat yang memiliki bangunan maupun yang sedang membangun. Hasil wawancara yang telah dilakukan pada hari Senin tanggal 3 Februari 2020 dengan Sekertaris Desa Bila yang mengatakan bahwa : "sebenarnya sosialisasi ini pernah dilaksanakan oleh pihak Pelayanan Terpadu Satu Pintu di Kecamatan Pitu Riawa pada tahun 2019 dengan mengundang masing-masing perangkat desa dan perangkat kecamatan dari Pitu Riawa, Dua Pitue dan Pitu Riase". Sedangkan data distribusi frekuensi variabel strategi sosialisasi dapat dilihat bahwa tingkat capaian responden yang diberikan adalah $58 \%$ yang terdiri dari 3 indikator proses sosialisasi yang dikemukakan oleh George Herbert Mead (Madya, 2018) yakni tahap persiapan, tahap siap bertindak dan tahap penerimaan norma kolektif. Berdasarkan hasil analisis data tersebut diperoleh capaian responden sebesar $58 \%$ yang berada pada kategori kurang baik dikarenakan penerapan strategi sosialisasi yang digunakan pihak pelaksana dinilai masih belum memberikan hasil yang optimal dalam pelaksanaan tugastugasnya terutama dalam hal sosialisasi izin mendirikan bangunan ini. Strategi sosialisasi izin mendirikan bangunan ini dikatakan optimal apabila masyarakat sudah tahu akan pentingnya kepemilikian izin mendirikan bangunan ini bagi yang sudah memiliki bangunan maupun yang sedang membangun.

Distribusi frekuensi faktor-faktor yang memengaruhi strategi sosialisasi izin mendirikan bangunan dapat dilihat bahwa tingkat capaian responden sebesar $57.4 \%$. Ini memperlihatkan bahwa nilai tingkat capaian responden yang diberikan berada pada kategori kurang baik ini dikarenakan kurangnya perhatian dari pemerintah terkait aturan izin mendirikan bangunan ini. Dalam peningkatan partisipasi masyarakat pada kepemilikan izin mendirikan bangunan diperlukan adanya informasi yang akurat sehingga masyarakat lebih mengetahui tentang bagaimana izin mendirikan bangunan ini. Pemerintah desa sebagai unsur politik yang paling dekat dengan masyarakat berperan penting dalam pemberian informasi dari pemerintah pusat dalam pencapaian tujuan izin mendirikan bangunan ini. Karena bagaimana pun juga, sosialisasi merupakan proses yang diikuti secara aktif dari dua pihak, pihak pertama adalah pihak yang mensosialisasikan dan pihak kedua adalah pihak yang disosialisasikan. Dalam hal ini adalah pihak pelayanan terpadu satu pintu dan masyarakat. Berdasarkan pengamatan saya, di Desa Bila sering diadakan sosialisasi dan partisipasi masyarakat cukup baik, akan tetapi untuk sosialisasi izin mendirikan ini memang belum pernah dilaksanakan di tingkat desa.

\section{KESIMPULAN}

Strategi Sosialisasi Izin Mendirikan Bangunan di Desa Bila Kecamatan Dua Pitue Kabupaten Sidenreng Rappang.

1. Hasil penelitian strategi sosialisasi izin mendirikan bangunan: a. Tahap persiapan: 1) Informasi sosialisasi izin mendirikan bangunan yang diberikan oleh pihak pelayanan terpadu satu pintu $60 \%$. 2) kemampuan pihak pelayanan terpadu satu pintu menggunakan media massa untuk mensosialisasikan izin mendirikan bangunan $56 \%$. 3) Kemampuan pihak pelayanan terpadu satu pintu mensosialisasikan izin mendirikan bangunan $58 \%$. b. Tahap siap bertindak tentang tata cara pihak pelayanan terpadu satu pintu mendorong masyarakat mengikuti sosialisasi izin mendirikan bangunan $58 \%$. c. Tahap penerimaan norma kolektif tentang kemampuan beerjasama dari pihak pelayanan terpadu satu pintu dengan pemerintah desa $58 \%$. Berdasarkan uraian tersebut, maka dapat disimpulkan bahwa strategi sosialisasi izin mendirikan bangunan di Desa Bila berada pada kategori Kurang Baik dengan persentase 58 \%. Hal ini dikarenakan penerapan strategi sosialisasi yang digunakan pihak pelaksana dinilai masih belum memberikan hasil yang optimal dalam pelaksanaan tugas-tugasnya terutama dalam hal sosialisasi izin mendirikan bangunan ini. Strategi sosialisasi izin mendirikan bangunan ini dikatakan optimal apabila masyarakat 
sudah tahu akan pentingnya kepemilikian izin mendirikan bangunan ini bagi yang sudah memiliki bangunan maupun yang sedang membangun.

2. Hasil penelitian faktor-faktor yang memengaruhi strategi sosialisasi izin mendirikan bangunan : a. Faktor eksternal : 1) Keadaan lingkungan Desa Bila sebagai tempat dilaksanakannya sosialisasi izin mendirikan bangunan 54 \%. 2) Hasil pekerjaan pihak pelayanan terpadu satu pintu melaksanakan sosialisasi izin mendirikan bangunan 58 \%. b. Faktor internal : 1) Dorongan atau motivasi yang diberikan pemerintah desa kepada masyarakat untuk mengikuti sosialisasi izin mendirikan bangunan 59 \%. 2) Tanggapan masyarakat Desa Bila untuk mengikuti sosialisasi izin mendirikan bangunan $56 \%$. 3) Kemampuan pemerintah desa menyampaikan sosialisasi izin mendirikan bangunan 60 $\%$. Berdasarkan uraian tersebut, maka dapat ditarik kesimpulan bahwa faktorfaktor yang memengaruhi strategi sosialisasi izin mendirikan bangunan di Desa Bila berada pada kategori Kurang Baik dengan persentase $57.4 \%$, dikarenakan kurangnya perhatian dari pemerintah terkait aturan izin mendirikan bangunan ini. Dalam peningkatan partisipasi masyarakat pada kepemilikan izin mendirikan bangunan diperlukan adanya informasi yang akurat sehingga masyarakat lebih mengetahui tentang bagaimana izin mendirikan bangunan ini. Pemerintah desa sebagai unsur politik yang paling dekat dengan masyarakat berperan penting dalam pemberian informasi dari pemerintah pusat dalam pencapaian tujuan izin mendirikan bangunan ini. Karena bagaimana pun juga, sosialisasi merupakan proses yang diikuti secara aktif dari dua pihak, pihak pertama adalah pihak yang mensosialisasikan dan pihak kedua adalah pihak yang disosialisasikan. Dalam hal ini adalah pihak pelayanan terpadu satu pintu dan masyarakat.

\section{E. REFERENSI}

Ahmad, Jamaluddin. 2015. Metode Penelitian $\begin{array}{lcc}\text { Administrasi } & \text { Publik } & \text { Teori } \\ \text { danAplikasinya. } & \text { Yogyakarta } & \text { : Gava } \\ \text { Media. } & & \end{array}$
Ghozali, Imam. 2009. Aplikasi Multivariate dengan program SPSS. Semarang : UNDIP.

Kamaruddin, S. (2016). Administrasi dan Pelayanan Publik antara Teori dan Aplikasinya. Yogyakarta: Ombak.

Nazir. 2005. Manajemen Kualitas Pelayanan. STIA LAN Press, Jakarta.

J. Salusu, 2006. Pengambilan Keputusan Strategik Untuk Organisasi Publik dan Organisasi Non Profit. Grasindo. Jakarta.

Akdon, 2011. Strategic Manajement For Educational Management (Manajemen Strategik untuk manajemen Pendidikan), Bandung : Alfabeta.

Setyoningtias, Dwi. 2018. "Pengaruh Sosialisasi, Persepsi, Citra Lembaga terhadap Motivasi Menabung."

Madya, Faisal. 2008. "Implementasi Kebijakan Izin Mendirikan Bangunan di Kabupaten Bogor".

Shobah. N. 2015. "Persiapan.” 18-42.

Suharyat, Yayat. 2009. "Hubungan antara sikap, minat dan perilaku manusia."

Saputra, David Surya Aji. 2017. "Implementasi Peraturan Menteri Pekerjaan Umum Dan Perumahan Rakyat Republik Indonesia Nomor 05/Prt/M/2016 Tentang Pengurusan Izin Mendirikan Bangunan Gedung Pada Pengembang Perumahan di Kabupaten Sleman Yogyakarta."

Astuti, Siwi Puji. 2015. "Pengaruh Kemampuan Awal dan Minat Belajar."

Marya. 2018. "Strategi Sosialisasi Dinas Kependudukan dan Catatan Sipil dalam Mengkampanyekan Wajib E-KTP pada Masyarakat Kabupaten Lamongan." 512.

\section{Dokumen-dokumen: .}

Peraturan Daerah Kabupaten Sidenreng Rappang No 2 Tahun 2011 tentang Retribusi Izin Mendirikan Bangunan 